\title{
Religion as the Process Driving Social Evolution
}

\section{Ken Baskin}

Institute for the Study of Coherence and Emergence

\begin{abstract}
For the purposes of this essay, we can think of religion as the human response to the realization that our lives, as individuals and in community, are frequently overwhelmed by forces we cannot control. Within this framework, myth becomes the stories about how to know and participate in those forces, and ritual becomes the way communities grapple with such forces and maintain the coherence they need to survive. Looking back through the history of the evolution of life, one can see how myth and ritual emerged as survival mechanisms that reflect human evolution over the last five million years. One can also see how, as the union of myth and ritual, religion would enable human groups to adapt to increasing social complexity, as communities grew from bands of 20 to cities of 20 million.
\end{abstract}

\section{INTRODUCTION}

Religion excites strong reactions, even from the most insightful thinkers: Freud compared it to a childhood neurosis (1989 [1927]); Marx (1844) called it the 'opium of the people'; Bertrand Russell described it as a 'disease born of fear and ... a source of untold misery to the human race' $(1957: 24)$. And these are only three of the dozens of descriptions that writers assign religion. Yet, almost all of them agree that religion is universal among human communities. In this paper, I hope to address this paradox: Why is it that even militant atheists, such as neuroscientist Sam Harris, who called it an 'uncompromising ... misuse of the power of our minds' (2004: 25), recognize that it is characteristically human? 
My speculation - and the ideas I present here are too new to be more than speculation - is that religion is an extraordinarily powerful phenomenon because it emerged as the uniquely human response to two survival challenges our evolutionary ancestors faced as they became Homo sapiens. As a result, it can address a range of critical, yet extremely varied questions, such as:

- How do we know the world just the way we must to survive?

- How can we create shared meaning?

- Why do we cooperate, even to the point of giving our lives for the group?

- How did our communities evolve from nomadic bands of 20 to cities of 20 million?

To make my argument, I shall examine four issues. First, I will touch briefly on the defining problem of religion studies. Then, I will examine how humans handled a survival challenge that all species have faced. Next, I will explore how our species took on a second survival challenge, one faced by all social animals. Finally, I will discuss how the product of integrating the answers to these survival challenges enabled our species to adapt to increasing social complexity since the Ice Age ended.

Many of the ideas I present here are built on the work of others, as much as a half-century old, such as anthropologist Anthony Wallace's (1966) ideas about how religion enables societies to adapt to radically changed circumstances. My model is unique in the way I have grounded it in a wide range of contemporary sciences, in fields ranging from Neurobiology to Complexity Theory and Evolutionary Developmental Biology. Yet, because my integration of work in those fields is still so new, I have likely made mistakes, perhaps serious ones. As a result, I want to invite my readers to respond to those mistakes or any issues I need to develop further.

And, with that invitation, let me begin with the definitional problem of religion.

\section{WHAT IS IN A WORD?}

Over and over, the literature on religion notes how difficult it is for thinkers to agree on a definition. William Cantwell Smith (1991 [1962]: 17) calls it 'notoriously difficult'; Bret Nongbri (2013) dis- 
cusses the problem's etymological source; Pascal Boyer (2001) notes the temptation to treat religion monocausally, the 'magic bullet' approach. But, for me, David Sloan Wilson says it most clearly:

The problem [with agreeing on a scientific definition] is not one of poor scholarship ... [but] an intellectual landscape that has impeded scientific progress in the past but need not impede progress in the future. In many ways, scientists and other intellectuals ... can't see what is in front of their faces because of what is in back of their faces - the ideas that organize perception (Wilson 2002: 132).

That is, the defining problem in understanding religion lies in our organizing ideas, the habits of thought we use to process what we experience. As a result, this paper will examine a different set of ideas, which come together in a different mental model. Using that model enables us to recognize that many of the existing definitions are valid, even when they contradict each other. However, before looking at that model, it is worth examining the traditional model and why it can mislead even first-rate thinkers.

The key to the problems with the current model of religion is historical. Religion, in Western culture, starting c. $1500 \mathrm{CE}$, has been anomalous, because of the events to which it had to respond (e.g., Baskin and Bondarenko 2014). And because everyone in the West writing today has grown up with this atypical conception of religion, it requires a conscious effort to overcome embedded habits of thought. Three ideas sit at the heart of this conception of religion:

- Belief: The current model of religion begins with the assumption, stated best by anthropologist Scott Atran, that religion demands belief in a 'counterfactual and counterintuitive world of supernatural agents' (2002: 4; author's italics). In this way, Daniel Dennett insists that religion often ends in a self-reinforcing belief in metaphysical beliefs (2006). Yet, belief did not become central until the battles between the Orthodox Church and the Gnostics in the second century CE (Pagels 1979). Before that, religion was not about what people accepted as true, but how they lived according to its practices (Nongbri 2013). Even Judaism, which invented the idea of 'true' and 'false' gods, remained a religion of practice (Akenson 2001). However, especially after the Religious Wars of the sixteenth and seventeenth centuries, what a person believed 
became central. Yet, the majority of writing on religion, like that of Atran, reflects this emphasis on unprovable belief.

- Separation from everyday life: With the Treaty of Westphalia (1649), which ended the Thirty Years War, religion transformed from an issue of cultural identity to a personal choice (Wilson 2009). As a result, religion became 'largely separate from other realms of life' (Winzeler 2012: 24), as its practices were reserved for the Sabbath and Holy Days. Western culture treats religion as an experience apart from earning a living, healing the sick, and governing society. Yet, for most of human history, religion was so integral to everyday life that no society even had a word for it (Nongbri 2013). Performing 'religious' rituals was part of how people in any society lived life. Such rituals, and the myths that informed them, were woven into cultural identity. It is, therefore, misleading to explore the origins and nature of religion as most Westerners practice it. Rather, it makes sense to examine the phenomena we call 'religious' in terms of why and how they came to be woven so tightly into daily life.

- Literal interpretation of text: Finally, in the current world, religious texts are generally interpreted literally, as in Atran's insistence on a 'counterfactual' world and supernatural agents. Yet, this extreme literal-mindedness only began to rise in the seventeenth century as the scientific worldview and the Reformation combined to eclipse an older understanding (Harrison 1998; see also Foucault 1994). As late as the Renaissance, people understood the world more symbolically; with the Scientific Revolution and the fragmentation of Christianity, even the Catholic Church began to give up its more metaphoric approach. It may be that most people have always accepted their cultures' myths literally. Still, as social scientists, I suggest we follow Joseph Campbell's (1969: 27) dictum: '[W]henever a myth has been taken literally its sense has been perverted.' Myth, and religion more generally, are not about an 'other' realm, but about life here and now, as we struggle with what J. Milton Yinger (1970) calls our 'ultimate problems' (see also Bellah 2011 and Rue 2005). This misunderstanding is especially strong in the idea of a watching, punishing, external God (e.g., Norenzayan 2015; Johnson 2016), which, as Joseph Campbell (2000) observes, appears to date from the Jewish use of the 
Persian King of Kings as a model for their God in the sixth century BCE. As social scientists, we are unlikely to understand religion as long as we think of Zeus and the biblical God as old men with white beards sitting in a real other world.

There is one other issue woven into the traditional model of religion that I want to emphasize - that is, the way thinkers on the subject use the word 'religion' to refer to three different meanings:

- First, religion can refer to a concept, an abstract generalization of all the myth-making, worship, and social ritual that are realized in specific practices at specific times and places. In this way, Yinger defines religion as 'a system of beliefs and practices by means of which a group of people struggles with [the] ultimate problems of human life' (Yinger 1970: 7).

- Second, religion can refer to an example of how religion as a concept emerges as social systems - Calvinism, for example, Jainism, or Daosim.

- Third, religion is used as if it were an active agent in the social world. In this way, religion creates morality (Winzeler 2012) or war (Dennett 2006).

These differences are often ignored or given short shrift. Some writers do not even consider these meanings worth discussing. Dennett (2006) does not define 'religion' as a concept, but only 'religions' as social systems. A few even dismiss religion as a concept, suggesting it is too wide-ranging a phenomenon to consider as a single entity (see Harrison 2007). For me, a satisfying discussion of religion would have to explain all three meanings and how they are related to each other.

In this essay, I want to put forward a model of religion that gets us beyond these habits of thought. To be as rigorous as possible in examining the subject, let me start with a definition that clarifies the three meanings of the word 'religion'. For me, religion, as a concept, is the way human groups use myth and ritual to understand and respond to the powerful, often mysterious forces that inspire awe and terror. The events these forces cause - from sickness and catastrophe to the quest for oneness with the universe, and, above all, death - are explored in myth in symbolic worlds of spirits and gods. Anthropologist Brian Hayden refers to the real world causes of these problems as the 'powerful forces that perme- 
ate things but cannot ordinarily be seen' (Hayden 2003: 57). In other words, myth (and therefore religion) emerges in response to the unconscious realization that humans live in a world full of forces that can overwhelm them. Myth, like science and philosophy, enables people to understand and participate in these forces. That is, religion, science, and philosophy can be viewed as three 'habits of inquiry' that may have emerged together in pre-AxialAge mythology (Baskin 2019).

For the purposes of this essay, I want to avoid examining this issue in detail. Note, however, that the earliest proto-science comes from the observation of natural cycles in Ancient Sumeria, Egypt, and China apparently for 'religious' reasons (Lindberg 2007). Even in Western Modernity, science was first thought of as Natural Philosophy, the study of God's Second Book (Nature) by figures such as Descartes, Newton, and Leibnitz, all of whom were deeply religious and philosophical (Gillespie 2009). From this point of view, religion, science, and philosophy are habits of inquiry that use different languages to examine the powerful forces that surround us: Religion examines them symbolically in myth; science does so with systematic observation; and philosophy discusses how people can best respond to these forces.

In addition, religious myths tend to be the most powerful stories any culture creates, as with the Garden of Eden story in Western culture (Greenblat 2017) or the rebirth myths of Ancient Egypt (Assmann 2001). The power of these stories, combined with the way they reflect the particular conditions of their times and places, made it possible for people in any society to apply them to a variety of social and cultural functions. Religion, then, can serve many functions. It begins with the quest to understand and participate in the world of invisible powers, spills over into creating social cohesion, and also becomes the blueprint for cultural institutions. Because religion serves so many purposes, and because it can be used from both selfish and altruistic motives, it should be no surprise that different writers - each with his or her own motives and perspectives - should describe it in so many, often contradictory ways.

With this definition in hand, I want to explore, first, the origin of myth; then, the way the accidents of human evolution integrated myth with ritualized behavior; and, finally, how religion emerged 
as the process by which humans would adapt to 10,000 years of increasing social complexity.

\section{THE FIRST EVOLUTIONARY CHALLENGE}

From the beginning of life, about 4 billion years ago, every species has wrestled with the challenge of surviving in a complex, continually changing world. More than a century ago, William James (1950 [1890]) pointed to this challenge when he described realityas-it-is, before perception, as a buzzing, formless mass of signals. Moreover, no living thing is able to sense more than a tiny sliver of that world, a 'tiny subset of the real patterns in the world of any agent' (Dennett 2017: 128; see also Laughlin and d'Aquili 1974). We human beings, for example, can see only a small fraction of all light waves, and our senses of smell and hearing are far duller than those of dogs. Given the superabundance of reality-as-it-is and the limitations of perception in any living thing, how do we survive? Apparently, in the process of evolution, the forces of natural selection choose those senses and nervous systems that enabled members of any species to experience what they must to survive (Hoffmann 2019; Hoffmeyer 2008). Jacob von Uexküll called the result an animal's umwelt, its inner, subjective world (von Uexküll 2010 [1934]). A bat's umwelt consists largely of the reflection of sound; a dog's, mostly of smell. Homo sapiens evolved sophisticated brain structures that automatically reduce the world spinning around them to a meaningful order by translating what happens around us into coherent story-like perceptions that give us the impression of walking through a living 'movie' (Laughlin et al. 1990; Gazziniga 2011).

Here, I use the word 'story' in a specific way. Any story must collapse a fictional or real world of events and details into a meaningful structure (Boje 2001). That is how people use the word when we ask a friend to give us the 'real story' or a TV reporter tells us to stay tuned for the 'whole story.' That is also the process by which our brains, at an unconscious level, construct images of the world and make those images conscious. In fact, neurobiologist Michael Gazzaniga (2011) uses the word 'story' to describe this process: Faced with an unfamiliar experience, the brain integrates a mélange of sense impression and memory, examines it all in light of the stories in which we encode our meaning structures, creates a series of 
possible explanatory stories for any event, and settles on the one that seems most accurate (e.g., Ramachandran 2011; Gazzaniga 2011).

Those stories must answer three questions: 1) What is happening? 2) What should I do? and 3) Why did that happen? With the most threatening experiences, the brain can process the first two in the amygdala instantaneously (Gazzaniga 2011). Whether confronted with a lion on the savannahs of Kenya or a yellow light turning red in Philadelphia, our brains immediately answer those two questions. The resulting explanatory stories enable us to choose to fight or run away from the lion, or to stop for or speed up at the yellow light. People who cannot answer these questions in a way that lets them succeed are less likely to survive.

The brain processes the third question a little later in the neocortex, the most recently evolved part of the brain. People, who cannot find an answer that fits in with personal models of the world, will feel disturbingly anxious (Laughlin et al. 1990). We Americans have experienced this anxiety in the last two presidential elections, half the population when Barack Obama was elected, the other half with Donald Trump.

This third question is especially important for understanding the origins of religion. Faced with the effects of Hayden's powerful, invisible, yet ubiquitous forces, the question 'Why did this happen?' quickly breaks down into two others: What is this wonderful yet frightening world of which I feel part? And how should I behave in order to thrive, or at least survive, in the face of the overwhelming forces that cause fear when the lion attacks and passion when my lover holds me, horror when my child is sick and terror when a flood destroys my village? To answer these questions, the human brain seems to have evolved several brain circuits associated with processing stories, including circuits that help human beings identify 'God as an object that exists in the world'; allows them to 'experience God's presence'; assign 'emotional meaning' to the concept of God; and create the impression of 'frightening, authoritative, and punishing God' (Newberg and Waldman 2010: 43). ${ }^{1}$

The myths of any specific religion explore these forces and how to deal with them in terms of a symbolic transcendent world - from the Heaven of Christianity to the very different Heaven of China or the Brahman of Hindu thought. Writers using the current model talk 
about that transcendent world as 'supernatural' (e.g., Dennett 2006), or 'counterfactual' (Atran 2002). Yet, those forces are very real parts of the natural world. So, I prefer to think to it as a world of impersonal forces. Especially for pre-literate societies, the most effective way to understand this world was to present it poetically, using the symbols of spirits or gods, as Joseph Campbell (1969) explains in writing that we pervert a myth when we interpret it literally. Myth is not a literal rendering of an 'other' world; rather it is made up of symbolic explanatory stories about life here and now.

As a result, from my point of view, mythic stories emerge as a way for people to address the challenges that they currently face (Rue 2005). Those stories also tend to express any society's symbolic order. This concept of a society's symbolic order is critical to understanding religion. While Homo sapiens may have emerged 250,000 years ago, the final step that made us Homo sapiens sapiens - fully human in the sense we think of it - came when we began thinking in terms of the world as symbolically coherent. Some writers believe that happened about 30,000 years ago, with the cave paintings of France (see Winzeler 2012). I find Brian Fagan's suggestion (2010) that the human mind became symbolically ordered about 70,000 years ago more convincing. Fagan explains that the eruption of Mount Toba in Indonesia created an environmental crisis that reduced the number of humans to as few as 10,000 . This is the kind of catastrophe that work in Evolutionary Developmental Biology (see Jablonka and Lamb 2005) indicates could have spurred such a significant evolutionary shift.

At that point, our species became what Terrence Deacon (1997) calls 'Homo symbolicus', the symbolic human, and our perceptual worlds became symbolically organized. Socially, that meant a set of shared symbolic models - the understanding of the way the world should be critical to any culture. Such a symbolic order provides the logic that lets people know what to pay attention to, what to ignore, and how to put together their experiences in a way that lets groups members share the meaning they assign those experiences.

At the heart of most symbolic orders are what Roy Rappaport (1999) examines as 'Ultimate Sacred Postulates' (USPs), the unquestionable ideas central to that order. In Judaism, the central postulate is the Shema: 'Hear, O Israel: The Lord is God, the Lord is 
One'; in Christianity, a similar postulate is the Trinity. Even the scientific Newtonian worldview, which has largely replaced Christianity in the Modern world, has its USPs - for example, the belief that the world is made up of distinct 'things' that interact according to Universal Laws of cause-and-effect. Some may object that science cannot be built on unproven assumptions, as a USP does. Yet, the last century of physics has made it clear that the world is far more highly interconnected than the Newtonian worldview allows (Laughlin 2005; Smolin 2013; Capra and Luisi 2014).

Mythic stories express their societies' symbolic orders. For example, humans have always experienced the Sun 'rising' in the East and 'setting' in the West. Egyptian religion explains it as the journey of the Sun god Re, in his boat, across the sky and then through the Underworld. In this way, the story emphasizes the cycle of birth (day), death (night), and rebirth (dawn), which was critical to the symbolic order of an agricultural society such as Egypt. The Ancient Greek story explains how Apollo drives his chariot across the sky every day to bring light. Light is a symbol of knowledge; in this way, the Greek story could emphasize the importance of knowledge, so central to the Greek symbolic order. The Modern Western story explains how gravity - one of the Universal Laws that govern how individual things interact, a key element of the West's symbolic order - keeps the Earth revolving around the Sun.

In these cases, each society was explaining the mysterious world of impersonal forces. Their mythic stories would embody the society's symbolic order and enable them to address these mysteries, whether in the mystery cults of Ancient Egypt, the worldview of Daoism, or today's equivalent, the mysteries of quantum mechanics (Goswami 2017). And poetry, which is symbolic and suggestive, is often the best way to describe and model the world of impersonal forces. The scientific counterpart is the models scientists create of phenomena in the world; they must often be suggestive, like poetry, because it is often impossible to describe them with certainty. In this way, we can think of Newton's belief that time and space were independent dimensions as a more-or-less poetic model, especially now that we understand how they are better conceptualized as interconnected time/space (Halpern 2015).

It is important to remember that the umwelt of any living thing whether the sonic world of a bat or the cultural world of the Chi- 
nese during the Han Dynasty - is a matter of survival. That percpetual world is the method that natural selection chose for them to model the chaotically abundant world as the species evolved. The apparent order provided by that model enables individuals to collapse the chaotic field of possible meaning into a constructed world, in which they can survive (Laughlin and d'Aquili 1974). The fact that humans depend on a culturally determined umwelt to survive creates two problems. First, it means that any challenge to a group's symbolic order may be experienced as an attack at members' survival. Current political battles over such questions as whether abortion should be legal are often experienced as an attack on the worldview of group members. To criticize my position is to question whether the symbolic order I survive with is true.

\section{THE UMWELT PARADOX}

Second, the mental models that result from any symbolic order are also reductions; they focus on certain parts of the world and overlook others. That means that anything not included can be perceived only with the greatest difficulty, if at all. This limitation is the Umwelt Paradox: Natural selection chooses the senses with which an animal creates its umwelt and, therefore survives. Yet, that umwelt also limits what the animal can perceive and make sense of, potentially making it vulnerable. To survive in a continually changing world, it is essential to include new things and eliminate others. For humans, that means switching out our symbolic orders from time to time (Kuhn 1962). This became one of the critical functions of religion.

When societies go through disruptive change, their old ways of living and governing society break down. If the society is to continue thriving, its mythic stories must be rewritten (e.g., Wallace 1966; Baskin and Bondarenko 2014). This is the Umwelt Paradox writ large. Take the case of China. From about 200 BCE to at least $1500 \mathrm{CE}$, China was the wealthiest, most civilized, most technologically advanced state in the world. So, when Europeans started appearing around 1500 , the Chinese were unimpressed. Their symbolic order had created a model that convinced them that these dirty, uncivilized people were no different from the many other subordinate peoples who had always collapsed in the face of their cultural superiority. Only this time, they were wrong, victims of 
the Umwelt Paradox. By 1800, they were becoming colonial subjects of the Western powers. Today, the Chinese have transformed their cultural umwelt and returned as one of the world's great powers. But to do that, they had first to recreate their symbolic order.

Current work in evolutionary anthropology suggests that the ability to create symbolically coherent models of the world did not emerge suddenly with the rise of Homo sapiens. It developed with the parts of the brain that are uniquely human - the areas of the pre-frontal cortex (e.g., Turner et al. 2018). Those areas are responsible for: expanded memory capacity; the ability to intertwine sight, hearing, smell and the feel of things; and the 'executive functions' that drive abstract thought, anticipation of the future, planning, and the construction of images (Laughlin et al. 1990: 116117). The neo-cortex and several associated, particularly welldeveloped structures - especially the thalamus, a relay station for sensory information, and the hippocampus, essential in learning and memory - make human beings story-creating animals.

Natural selection appears to have chosen the brain structures that make humans born storytellers during the last five-to-seven million years, when the common ancestor of humans, chimpanzees, and bonobos broke off from the great apes of East Africa (d'Aquili et al. 1979). This was a period of especially rapid climate change (Fagan 2010). Perhaps the abilities to remember and communicate how the group's ancestors dealt with the last set of changes favored the changes in brain structure that caused this increase in the ability to remember and plan. Notice how dramatically brain size has grown:

- Chimpanzee skulls are about $350 \mathrm{cc}$ in volume;

- Australopithecus afarensis, which appeared about three million years ago, about $450-500 \mathrm{cc}$;

- Homo erectus, from about 1.8 million years ago, about $880 \mathrm{cc}$;

- Modern Homo sapiens, often dated from about 250,000 years ago, has a skull of about $1350 \mathrm{cc}$ (Fagan 2004).

A great deal of this increasing size makes room for development in the neo-cortex. As a result, Biogenetic Structuralists Eugene d'Aquili and Charles Laughlin (1979) suggest that the brain structures that enable the human capacity for abstract thought and executive functions may have been present as early as the australopithecines (see also, La Barre 1977). 
Merlin Donald (1991) takes the argument one step further. He suggests that, by the time of Homo erectus (sometimes called Homo ergaster) c. 1.8 million years ago, our evolutionary ancestors began to use their increasing neo-cortex to represent events to each other in creative mime and imitation, in what he calls 'mimetic culture.' As a result, it may be possible to trace early 'religious' behavior back to Homo erectus (see also Dunbar 2016 and Everett 2017). Without symbolic language, which only developed with our species, it may seem odd to claim that our evolutionary ancestors could practice anything like religion. And such a proto-religion would have been very different. However, they might have been able to communicate their proto-myths by hijacking another survival strategy - the use social animals make of ritual to enhance group coherence.

\section{THE PUZZLE OF SOCIAL ORDER}

Julian Huxley (1966) called that survival strategy the 'ritualization of behavior'. It seems to have emerged over the last 150 million years as some animals became more and more dependent on cooperation to survive. These 'social animals' range from ants and bees to cockatoos, wolves, and chimpanzees. They often rear their young cooperatively, live with several generations in permanent settings, hunt and defend the group together, and rely on group learning. Social animals can have complex societies, with defined roles and hierarchy. As a result, they need ways to communicate complex messages quickly and effectively, as well as to commit to the demands of their hierarchies (d'Aquili et al. 1979).

Some of this behavior, which ethologists call 'fixed action patterns', is mostly a matter of genetic programming (Huxley 1966), the mating ritual for example. A butterfly, called the silver-washed fritillary, has a seven-step ritual: The male begins with a first signal, and the female makes a countersignal, through seven steps (d'Aquili et al. 1979). While this 'ritual' is fixed in the butterfly's genes, similar fixed action patterns in birds and mammals are often learned. A good example is the songs birds in some species sing to signal they are members of a specific group.

The more complex the social group, the more important these ritualized behaviors become. Many mammals, wolves for instance, have highly complex group dynamics. Wolves within a pack can 
have different temperaments and roles; they cooperate in hunting and have social hierarchies. So, they need ways to communicate complex messages. In one ritualized pattern, the leader parades a bone in front of the pack, then drops it so the rest of the pack can inspect, and then ignore it (d'Aquili et al. 1979). As a result, social animals can communicate complex messages - 'I am your leader/follower' or 'I am approaching you not to hurt you but to negotiate sex' - without language. They also enable group members to commit to the social hierarchy, as with wolves. Or build trust between members, as with primate grooming and human gossip (Dunbar 1996). (For a fuller discussion of the pre-human origins of such 'ritual' behavior, see d'Aquili et al. 1979.)

However, understanding how human beings adapted ritualized behavior to create group cohesion opens a much-discussed difficulty: The Great Altruism Debate. Dawkins refers to it as "that perennial problem, the evolution of "altruistic" behavior in individuals' (Dawkins 1996: 381; see also Boyer 2001; Johnson 2016; Boehm 2012). In evolution, some writers argue, survival always comes first, favoring the 'selfish.' Yet human society demands cooperation, especially in today's large societies where most people do not know each other. How, then, can essentially selfish people be brought to cooperate and even act in ways that risk their own well-being for others, as New York City's first-responders did during the events of 9/11?

This debate also reflects an evolutionary curiosity: Human beings are intensely social animals, depending on each other for survival. Yet, they evolved from the great apes, such as gorillas and orangutans, as loosely connected to each other as humans are tightly woven. Turner and his co-authors (2018) explain the biologic evolution that made this transformation possible. When our hominin ancestors left the rain forests of East Africa, they moved into more dangerous environments. As with the hunting/scavenging parties that 'brought home' meat, their survival was enhanced by depending on each other. As if to enhance that cooperation, natural selection chose for a wider palette of emotions starting about three million years ago, the 'biologically-based propensities for human reliance on religion' (Ibid.: 2). Turner and his co-authors even suggest that the nuclear family developed partly as a result of changes in the brain. For example, the septum, associated with sexual pleasure, 
doubled in size from the great apes to humans, enabling a much more intense relationship between partners.

My model suggests that the real value of the understanding of the impersonal forces provided by mythology was in enabling people in a society to work together to face them. As a result, natural selection may well have chosen ritualized behaviors both to enhance communication and group cohesion. By the emergence of Homo erectus, about 1.8 million years ago, 'proto-religious' ceremonial rituals may have become central to group life (Donald 1991). While linguist Daniel Everett (2017) recently argued that language developed with Homo erectus, even if he is wrong, mimetic 'rituals' could have been an early form of storytelling about the impersonal forces of the universe. Without sophisticated symbolic language, such mimetic 'stories' would have been very different from what we now consider myth. Still, some sort of storytelling about the sometimesterrifying impersonal forces of the universe seems possible.

The idea that Homo erectus could tell stories is speculative and certainly open to argument. Still, it is difficult to imagine how Homo erectus could spread across the globe, from Spain to Indonesia, without some form of storytelling, if only for exchanging information about their travels and for teaching needed skills. However, with Neanderthals, burial rituals suggest a form of storytelling about the invisible world was even more likely (Rossano 2010; Turner et al. 2018).

When most people hear the word 'ritual', they think of highly formalized ceremonies, repeated on special occasions, and performed in a way participants understand to be unchanging (Rappaport 1999). Such ceremonial rituals are most often associated with religion (Catholic Mass) or government (Presidential Inauguration in the United States). Human ritualized behaviors range from these ceremonies to extremely informal actions, such as handshakes or the etiquette for introducing people (d'Aquili et al. 1979). In between is a range of activities, from sporting events to business meetings to birthday parties. In these examples, the degree of ritualization varies. But all of them are, to some extent, ritualized behaviors that enable community members to communicate complex messages and draw tentative conclusions about other participants. The ritual elements of sports are so powerful that they often cause fan violence in football, both American and non-American. 
Among humans, these ritualized activities fulfill several functions (Rappaport 1999; Seligman et al. 2008). First of all, rituals enable group members to remember key elements of their symbolic order, as they regularly perform those rituals. As an aid to memory, such rituals almost certainly became more important with the growth in the size of cultural communities, after the end of the Ice Age. This growth may have been most difficult as the 20-person huntergatherer bands grew to cities, such as Uruk, of 40,000 by about 5,000 years ago (Modelski 2003). As a result of this growth in population, and of social complexity, mismatches developed between the behaviors humans in hunter-gatherer bands evolved to survive in a world where they were deeply dependent on Nature and those needed in their brave new world of agriculture and cities, which they were increasingly able to form and control (van Schaik and Michel 2016; also Baskin and Bondarenko 2014). To adapt to these mismatches, people seem to have developed mythic stories about responding differently in a very different, more complex world. Rappaport calls it an 'as-if' world - unlike that of hunter-gatherer bands. Ritual enabled them both to remember and maintain that order; as Rappaport (1999: 137) puts it, 'the existence, acceptance, and morality of conventions are joined together indissolubly in rituals.'

These rituals also educate the young on the nature of their symbolic, 'as-if' world. Many elements of children's play end up being practice for the behaviors and roles they learn in those rituals (Seligman et al. 2008). This should hardly be surprising. As noted earlier, human beings can only create and share meaning by learning the symbolic order they have in common. That is, children have a biological imperative to learn their society's order. Play enough at the behaviors and roles coded into these rituals and they become second nature. Through physical reenactment of our social stories, each of us can thus form a variation on the umwelt shared in our societies.

In addition, rituals enable group members to communicate historically important information, such as action plans for previously experienced disasters, such as periodic famines or floods (Rappaport 1999). In pre-literate societies, preserving such action plans would have required oral mythic stories, enacted in ritual. This sort of ritual is also valuable in literate cultures, as in the Jewish ritual of the Pesach sedar. The sedar ceremony is an annual discussion of 
the exodus from Egypt, a ceremony which God commands in Exodus 13:8, during which participants are encouraged to experience the story as if they were actually leaving Egypt. Is it a mere coincidence that this ritual has been enacted throughout Jewish history? It became a yearly rehearsal for the next cycle of being valued strangers in a strange land, becoming oppressed, and leaving, repeated, as in their exiles from England in 1290 and Spain in 1492.

When explanatory stories and ritual came together in religion, they provided a way for people in their societies to remember and enact their symbolic orders, to commit to their groups, and to pass on knowledge of it. And when their worlds changed so much that the old symbolic orders no longer worked, religion provided the tools that enabled those societies to evolve new survival strategies. I want to finish this paper with a discussion of how this concept of religion evolved, from its beginnings in hunter-gatherer bands to the nation-states that dominate the world today.

\section{THE CULTURAL EVOLUTION OF RELIGION}

If my speculations are accurate, some form of proto-religion may have emerged, perhaps as early as 1.8 million years ago, as the human storytelling umwelt and ritualized behavior for social coherence came together. This proto-religion would have been invaluable as Homo erectus migrated across Eurasia, adapting to environments from those in Ice Age Europe to the jungles of India, as they created new versions of their stories about the impersonal forces of the universe to help them survive. However, even if my 'start date' is wrong, the basic dynamics are worth thinking about. After all, as natural selection refined the large brain, our evolutionary ancestors, such as Homo heidelbergenis and Homo neanderthalensis, living in small bands, may have practiced early forms of proto-religion (Turner et al. 2018). By the time Homo sapiens first emerged, relatively sophisticated language would have been added. Still, while the sophistication of this early religion would have increased, at some point in relatively recent history, it would have become much more like what we know as religion.

When language was combined with symbolic order, religion as we think of it was ready to develop. These early symbolic orders may not have had a major practical impact immediately. People 
still lived in hunter-gatherer bands, a more-than-million-year-old social structure. As a result, the personal and social functions that religion would fulfill might well have been experienced as part of the habitual hunter-gather style of life.

However, about the time the Ice Age began to end c. 12,000 years ago, these communities became rooted in one place and began to grow to hundreds and, then, thousands. At that point, humans likely experienced the Umwelt Paradox, and religion could serve a set of new functions, enabling these communities to create the new social structures for their more populous, less-egalitarian, and more complex communities. Especially with the growth of agriculture, a new set of problems arose for a species that had evolved in small groups, but now had to deal with the problems of larger groups, including the diseases that appeared with agriculture (see especially van Shaick and Michel 2016).

In The Axial Ages of World History, Dmitri Bondarenko and I propose that human history can be understood as three cycles of social stability and transformation (Baskin and Bondarenko 2014):

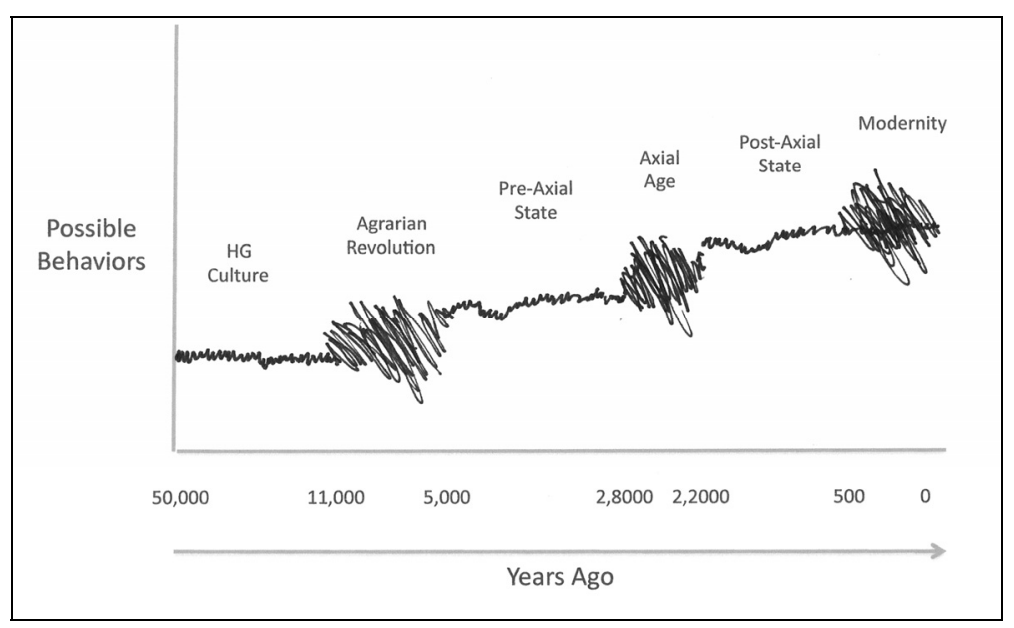

Fig. 1. Human Cultural Evolution

In each stable period, a particular style of social structure and governance largely dominated the most powerful human groups. During that stable period, changes in climate and population, technology and trade eventually overwhelmed the ability of those groups 
to govern themselves. During each transformational period, the old ways broke down, invoking the Umwelt Paradox and creating the demand for a new mythology that would enable people to adapt to new conditions. As a result, a variety of experiments evolved, competing for membership among people who were now looking for a better way to live. The experiments best able to meet the spiritual needs of the time and create cohesive social groups would eventually win out and become recognized by the state. In this way, the postAxial-Age world would be dominated by Christianity in Europe, Islam in the Middle East, and variations of Confucianism in China.

I am convinced that this evolution of religious thought and practice is at the heart of the process by which human groups have resolved the Umwelt Paradox. You may remember that I defined religion as the use of myth and ritual to deal with powerful forces. I have already discussed mythic 'thought' and ritual 'practice'. For the rest of this paper, I want to examine how religion ended up filling a variety of functions as it was employed to address these forces. To understand how these functions enabled human groups to transform their way of understanding and surviving in the world, consider the five listed below and how they developed during and after the Axial Age. (The asterisks for Functions 2 and 3 indicate that they are both personal and social.)

Table 1

Matrix of Functions

\begin{tabular}{|l|l|l|}
\hline \multicolumn{1}{|c|}{ Function } & \multicolumn{1}{|c|}{ Purpose } & \multicolumn{1}{|c|}{ Motivation } \\
\hline Personal & \multicolumn{1}{|c|}{$\begin{array}{l}\text { Connect with imperson- } \\
\text { al forces }\end{array}$} & $\begin{array}{l}\text { Fearless/fearful } \\
\text { search }\end{array}$ \\
\hline 1. Spiritual & $\begin{array}{l}\text { Create adaptive symbol- } \\
\text { ic order }\end{array}$ & $\begin{array}{l}\text { Fearless/fearful } \\
\text { knowing }\end{array}$ \\
\hline 2. Epistemological* & $\begin{array}{l}\text { Know self and 'us'vs. } \\
\text { 'them' }\end{array}$ & $\begin{array}{l}\text { Self-knowledge/ } \\
\text { fear of other }\end{array}$ \\
\hline 3. Identity-oriented* & Demonstrate commit- & Cooperation/fear \\
\hline Group & ment & Cohesion/control \\
\hline 4. Promissory & Mythicize hierarchy & \\
\hline Societal & \multicolumn{2}{|c|}{} \\
\hline 5. Ideological & \multicolumn{2}{|c|}{} \\
\hline
\end{tabular}

To illustrate, let us consider the transformation that occurred during and after the Axial Age (c. 800-220 BCE) and the powerful 
forces, developing in pre-Axial-Age states, that drove it. First, population increased in the largest cities from about 40,000 in Uruk c. $3000 \mathrm{BCE}$ to 150,000 in Thebes (Egypt) and 120,000 in Yin (China) c. $1200 \mathrm{BCE}$ (Modelski 2003). Second, iron metallurgy was spreading rapidly even before 1200 . Iron weapons were cheaper and more widely available than the bronze ones they replaced (Anthony 2007). Along with domestication of horses, it would now be possible to have far larger armies. By the end of the Axial Age, Chinese armies counted their soldiers in hundreds of thousands (Lewis 1971). Horses also made it possible for armies to move faster and further. As a result, the pre-Axial states started becoming vast empires, which would make it necessary to develop group identities that included a far wider variety of people (Harper 2017). Finally, spread of writing beyond commerce and government drove a rapid increase in the amount of available knowledge and the way societies communicated their cultures.

In Greece and Israel, India and China, these changes overwhelmed existing societies. To resolve the resulting Umwelt Paradox, their religions would be transformed from the polytheistic religions grounded in orally created myth to the Religions of the Book - monotheism in Europe and the Middle East, Buddhism in India, and a mix of Confucianism, Daoism, and Buddhism in China. While these religions evolved in different time sequences to serve very different cultures, the process by which China's axial 'hundred schools' of philosophy was set on the road to becoming Neo-Confucianism, and Christianity moved toward becoming the state religion of the Roman Empire, for example, are remarkably similar. Because their cultures were so different, I will focus on these two examples for the rest of this paper.

These religions began to emerge in times when social breakdown demanded different ways of being both as individuals and together in their societies. China's 'hundred schools' of philosophy responded to a time of violent devastating warfare, which had destroyed what was remembered as the peace and abundance of the Western Zhou Dynasty, c. 1100-771 BCE (Fairbank and Goldman 2006). Similarly, Christianity arose during the first century CE, when it seemed the Jewish God had abandoned his Chosen People, reneging on the promises $\mathrm{He}$ had made in the biblical writings of 
the fifth century BCE (Akenson 2001). At the same time, the old Roman state was having difficulty caring for its people (Stark 2011) and developing an ideology that could unite everyone in its empire.

These axially inspired religions began in the spiritual quests (F1) of individuals seeking to be one, and to put themselves right with, the powerful forces responsible for the chaos they experienced. Confucianism and Christianity would be identified with their semi-mythic founders. For Confucius, China's chaos resulted from leaving behind the Way of their ancestors, as illustrated by the period of peace and prosperity during the Western Zhou Dynasty. A return to the old ways was therefore necessary. For Jesus, the chaos of Israel was the result of the imminent End of Times in a battle between the cosmic forces of Good and Evil. As a result, he preached a pure form of Judaism for those who were with God and His forces of Good (Akenson 2001).

The story of their spiritual seeking would be recorded by others in their circles - as the New Testament Gospels, for example, or Confucian Analects. One reason that religion as a concept becomes so complex is that different spiritual seekers interpreted these masters' teaching from different motivations. While the Gospels present a loving God, the Book of Revelations cultivates fear of eternal damnation. Similarly, in Axial-Age China, the writings of Confucius are motivated largely by the desire for people to behave with ren, essentially humanness. Yet the insistence on obeying authority and observing social conventions suggests a basis in fear.

The answers that leaders in Chinese religion/philosophy and Christianity negotiated to these spiritual questions next took on two personal functions - the Epistemological (F2) and Identity-oriented (F3) - each of which also fulfills a social function. As noted earlier, each of us need a symbolic order, personally, to make sense of the world, and socially, so that they can understand each other (F2). To create that order, the followers of figures such as Confucius and Laotzi in China and Jesus, first in Israel, then outside, developed what would become a generally-accepted interpretation of their founders' stories.

In both Axial-Age China and the post-Axial-Age world of Imperial Rome, a similar dynamic appeared as they negotiated their sym- 
bolic orders. In China, Confucians insisted that the Way was strict adherence to prescribed ritual and behavior. Daoists responded that insistence on 'proper' behavior resulted in people mimicking that behavior while often doing the opposite. For them, the Way (Chinese $D a o$ ) was to unlearn social conventions, align oneself with the natural flow of the world, and practice $w u$-wei, translated as 'nonaction' or 'effortless action' (Schwartz 1985; Slingerland 2003). $W u$-wei is much discussed, but it can probably best be understood in terms of Hindu thought: action which does not create karma, as others respond, but takes advantage of the natural flow of events in the world. Such action comes from feeling part of the universe, rather than social convention and morality.

Similarly, early Christianity experienced the opposition between the leaders of the Orthodox Church, who would decide which Gospel stories would be included in the Bible, and the Gnostics, whose gospels were found mostly among the Dead Sea Scrolls (Pagels 1979). This debate may best be understood in the interpretations of what Jesus meant when He said, 'I am the way, the truth, and the life: no man cometh unto the Father, but by me' (John 14:6). For the Orthodox, the way of Jesus came through the Church. The only way to salvation was to bow to the authority of that Church and its ordained priests. For the Gnostics, salvation was a matter of knowing Jesus personally through a spiritual search.

So, with Christianity, the Orthodox seem much like the Confucians, while the Gnostics seem like the Daoists. Once again, we can see how the Epistemological function can be shaped by motivation, with the Orthodox and Confucians acting from a need to maintain social control, while the Gnostics and Daoists desire to be part of the sacred order for its own sake. The development of these two religions suggests a difficulty we see over and over. Because life can be so terrifying, those motivated by fear and the need to control often triumph over the spiritual seekers, creating epistemologies that make personal spiritual seeking more difficult.

The Identity-oriented function of religion (F3) is also both personal and social. As children, all human beings learn and identify a 'story' about who they are in relation to the groups that make their survival possible. Until Modernity, that identity was encoded in the group's shared religious epistemology. Such identities are 
essential to both the individual, who needs to know how to behave within the group, and for the groups, whose members need to distinguish between group members and Others (Rappaport 1999; Seligman et al. 2008). The expansion of the pre-Axial-Age state to the post-Axial-Age empire, incorporating people with very different languages and backgrounds, made forging new identities especially important during and after the Axial Age.

In China, forging this new identity may have been simpler than in the Roman Empire. Confucius was formalizing Chinese traditional beliefs, ancestor worship, for example, and the understanding that life on Earth should reflect the Way of Heaven (Schwartz 1985). By ritualizing almost every element of life, Confucius created a path to order, at a disturbingly disordered time, and grounded it in pride in a rich historical tradition. One element that would enable the Chinese sacred order to be successful over the next millennium and a half was that the rigidity Confucian thought might have pushed China toward could be complemented with Daoism, so that the ideal emperor could be Confucian on the outside and Daoist on the inside, as the two religions adapted to each other (Graham 1989).

While Christianity drew on the group - of the Jews - it would develop a more innovative way of being in the world. At first, the Christian community based in Jerusalem worked to reform Judaism. However, after the Romans destroyed the Second Temple in $70 \mathrm{CE}$ and, Christianity began loosening its dies to Judaism, as Paul networked almost-entirely non-Jewish Christian communities (Stark 2011). The message of loving your brothers in Christ shaped an identity that would overcome the state-centeredness of the old Roman religion. Moreover, the careful integration of 'pagan' customs, as with the adoption of Egyptian iconography in the 'worship' of Isis and Horus - as Earth Mother Mary and Child Savior Jesus - made it easier for those in other religious cults to join. Once again, in both personal and social functions, people could adapt these identities either from a desire to understand self or as a way of telling the difference between 'Us' and 'Them.'

Another important social function is Promissory (F4). As Rappaport (1999) observes, by participating in religious rituals, individuals commit to the group and its goals. Built on top of shared 
meaning and identity, this promise becomes especially strong. It not only enables each individual to commit to the group, but also allows everyone else participating to witness that commitment and judge later acts that might go against it.

In China, the promissory function helped build especially cohesive communities, because Confucianism structured society, ritualistically, into power dyads (e.g., Schwartz 1985) - king/counsellor, husband/wife, father/son, older/younger brother. In each relationship, the superior partner has both the power to direct and the responsibility to protect the lesser. As a result, post-Axial-Age Chinese would demonstrate their commitment to the community in almost every action. Moreover, with these clear lines of authority, the father of a family or mayor of a town becomes responsible for the actions of those who answer to him, and control could be created more informally than in Western communities, which would rely far more on law to create social order.

With Christianity, this ritual commitment to the demands of shared identity also bolstered social cohesion. As in China, the promissory function extended beyond participation in distinctly religious activities. The Orthodox Church also used it to enforce the authority - rendering unto Christ and Caesar - that made this religion such an effective tool of Rome, once Constantine accepted Christianity. By participating in the Christian community people were committing to the Orthodox doctrine, making the charge of heresy especially powerful.

Once again, this function could rise from positive or negative motives. In both cases, it could create social cohesion or be used to appeal to the fear of the Other, respectively.

For the empires that developed them, Chinese philosophy/religion and Christianity served several societal functions. Perhaps the most important is Ideological, providing a mythic justification (F5) for the differences in wealth and power within them. In China, social structure reflected the Mandate of Heaven (Fairbank and Goldman 2006). According to this principle, the rise and fall of Chinese dynasties reflected the ability of leaders to meet their responsibilities, including both ritual responsibilities and proper application of justice. Similarly, the Christian principle of Original Sin, which became Church dogma in the first half of the sixth century CE, made 
it clear that people were so sinful they needed the guidance of their king in secular matters and the Church in spiritual ones. In both cases, any person's place in the social structure was the will of Heaven/God. Where both these justification could reflect a sincere desire for a peaceful, ordered society, they were more often abused by the powerful, for whom the will of Heaven and God were excuses for their doing exactly what they wanted.

This analysis of the functions religion fills is far too short. A full list would include about a dozen functions. Still, I hope I have demonstrated the value of developing this model of religion. For one thing, it explains the conflicts between the views of writers such as Russell and James, mentioned at the beginning of this essay. Religion as a concept emerges as the human habit of inquiry that meets the need to 'know' an unknowable reality. The brain mechanisms that developed to do that portray the world we can perceive as story-like constructions that explain, in a symbolically coherent way, the nature of the world of impersonal forces and how we must behave to survive in it. Those stories proved to be so powerful that they were also used to maintain group coherence and cooperation. Finally, as the number of people in human communities increased, they could guide the structure of the states and empires that grew out of the hunter-gatherer bands that existed for most of human history.

The use of individual religious traditions, reflecting local variations of religion, as a concept, for so many functions, by people with such different motivations, all but guaranteed powerful contradictions. When the Orthodox Church insisted that it was the one true way, it made practicing the Gnostic sort of spiritual quest which had characterized Jesus and his followers. When Constantine adopted Christianity into the Roman Empire, he created exactly the sort of non-local social cohesion that an empire needs. At the same time, he made it possible to kill strangers for the greater glory of the King of Peace. Today, that contradiction may be even more distressing, as Indians (Hindu) and Pakistanis (Muslim) point nuclear weapons at each other and the Buddhists in Myanmar persecute Muslim Rohingyas.

Most important for me, this model helps explain why almost every writer on the subject agrees that religion is a human univer- 
sal. When I started thinking about religion, I wanted to write about how the human imperative to transform experience into story-like constructions would explain myth. But the more I examined religion, the more I realized that the many, often contradictory positions that writers took reflected a far more interesting possibility. Religion, as a concept, reflects the deepest necessities of surviving as a human being: religion is how we know the world, how our extremely social species holds its groups together, and how we have adapted to ten thousand years of increased social complexity. As a result, the contradictions that mark the history of religion reflect the contradictions of being human, especially in social environments utterly different from those we evolved in.

In short, the central conclusion my model of religion points to is this: To understand being human, we have to understand religion. And to understand religion, we have to look deeply into what it means to be human.

\section{NOTE}

${ }^{1}$ I wrote this essay before I became aware of the Congitive Science of Religion (CSR), one of today's leading schools of religious thought. Like members of that school, such as Atran, cited above, I make extensive use of discoveries in Neurobiology, Cognitive Science, and Evolutionary Studies. The main difference between my approach and that generally taken in CSR is that members of this school most often continue to be guided by the dominant mental model of religion, especially in their literal interpretation of religious texts and their emphasis on belief.

\section{REFERENCES}

Akenson, D. H. 2001. Surpassing Wonder: The Invention of the Bible and the Talmuds. Chicago, IL: University of Chicago Press.

Anderson, B. 2006. Imagined Communities: Reflections on the Origins of Nationalism. London: Verso.

Anthony, D. W. 2007. The Horse, the Wheel, and Language: How BronzeAge Riders from the Eurasian Steppes Shaped the Modern World. Princeton, NJ: Princeton University Press.

Assmann, J. 2001. The Search for God in Ancient Egypt. Transl. by D. Lorton. Ithaca, NY: Cornell University Press.

Atran, S. 2002. In Gods We Trust: The Evolutionary Landscape of Religion. Oxford: Oxford University Press.

Baskin, K. 2019. Toward A Big History Interpretation of Religion. Journal of Big History, 3 (4): 147-166. 
Baskin, K., and Bondarenko, D. M. 2014. The Axial Ages of World History: Lessons for the $21^{\text {st }}$ Century. Litchfield Park, AZ: Emergent Publications.

Bellah, R. N. 2011. Religion in Human Evolution: From the Paleolithic to the Axial Age. Cambridge, MA: The Belknap Press.

Boehm, C. 2012. Moral Origins: The Evolution of Virtue, Altruism, and Shame. New York: Basic Books.

Boje, D. M. 2001. Narrative Methods for Organizational and Communication Research. London: Sage Publications.

Boyer, P. 2001. Religion Explained: The Evolutionary Origins of Religion. New York: Basic Books.

Campbell, J. 1969. Primitive Mythology: The Masks of God. New York: Penguin Books.

Campbell, J. 2000. Mythos II: The Shaping of Our Mythic Tradition. The Joseph Campbell Foundation.

Capra, C., and Luisi, P. L. 2014. The Systems View of Life: A Unifying Vision. Cambridge: Cambridge University Press.

D'Aquili, E. G., Laughlin, C. D., and McManus, J. (eds.) 1979. The Spectrum of Ritual: A Biogenetic Analysis. New York: Columbia University Press.

Dawkins, R. 1996. The Blind Watchmaker: Why the Evidence of Evolution Reveals a Universe without Design. New York: W.W. Norton \& Co.

Deacon, T. 1997. The Symbolic Species: The Co-Evolution of Language and the Brain. New York: W.W. Norton \& Co.

Dennett, D. C. 2006. Breaking the Spell: Religion as a Natural Phenomenon. New York: Penguin Books.

Dennett, D. C. 2017. From Bacteria to Bach and Back: The Evolution of Minds. New York: W.W. Norton \& Co.

Donald, M. 1991. Origins of the Mind: Three Stages in the Evolution of Culture and Cognition. Cambridge, MA: Harvard University Press.

Dunbar, R. 1996. Grooming, Gossip, and the Evolution of Language. London: Farber and Farber.

Dunbar, R. 2016. Human Evolutoin: Our Brains and Behavior. Oxford: Oxford University Press.

Everett, D. L. 2017. How Language Began: The Story of Humanity's Greatest Invention. New York: W.W. Norton \& Co.

Fagan, B. M. 2004. People of the Earth: An Introduction to World Prehistory. $11^{\text {th }}$ ed. Upper Saddle River, NJ: Pearson/Prentice Hall.

Fagan, B. M. 2010. Cro-Magnon: How the Ice Age Gave Birth to the First Modern Humans. New York: Bloomsbury Press.

Fairbank, J. K., and Goldman, M. 2006. China: A New History. $2^{\text {nd }}$ ed. Cambridge, MA: The Belknap Press. 
Foucault, M. 1994. The Order of Things: An Archaeology of the Human Sciences. New York: Vintage Books.

Freud, S. 1989 [1927]. The Future of an Illusion. New York: W.W. Norton \& Co.

Gazzaniga, M. S. 2011. Who's in Charge? Free Will and the Science of the Brain. New York: HarperCollins.

Gillespie, M. A. 2009. The Theological Origins of Modernity. Chicago: University of Chicago Press.

Goswami, A. 2017. The Everything Answer Book: How Quantum Science Explains Love, Death and the Meaning of Life. Charlottesville, VA: Hampton Roads Publishing Co.

Graham, A. C. 1989. Disputers of the Tao: Philosophical Argument in Ancient China. Chicago, IL: Open Court Publishing Co.

Greenblatt, S. 2017. The Rise and Fall of Adam and Eve. New York: W.W. Norton \& Co.

Halpern, P. 2015. Einstein's Dice and Schrödinger's Cat: How Two Great Minds Battled Quantum Randomness to Create a Unified Theory of Physics. New York, NY: Basic Books.

Harper, K. 2017. The Fate of Rome: Climate, Disease, and the End of an Empire. Princeton, NJ: Princeton University Press.

Harris, S. 2004. The End of Faith: Religion, Terror, and the Future of Reason. New York: W.W. Norton \& Co.

Harrison, P. 1998. The Bible, Protestantism, and the Rise of Natural Science. Cambridge: Cambridge University Press.

Harrison, V. S. 2007. Religion and Modern Thought. London: SCM Press.

Hayden, B. 2003. Shamans, Sorcerers, and Saints: A Prehistory of Religion. Washington, D.C.: Smithsonian Books.

Hoffman, Donald. 2019. The Case Against Reality: Why Evolution Hid the Truth from Our Eyes. New York: W. W. Norton \& Co.

Hoffmeyer, J. 2008. Biosemiotics: An Examination into the Signs of Life and the Life of Signs. Scranton, PA: University of Scranton Press.

Huxley, J. 1966. Ritualization of Behavior in Animals and Man. URL: unesdoc.unesco.org/images/0015/001560/156054eb.edu. Accessed 17.03.2017.

Jablonka, E., and Lamb, M. J. 2005. Evolution in Four Dimensions: Genetic, Epigenetic, Behavioral, and Symbolic Variation in the History of Life. Cambridge, MA: The MIT Press.

James, W. 1950 [1890]. The Principles of Psychology. New York: Dover Press. 
Johnson, D. 2016. God Is Watching You: How the Fear of God Makes Us Human. Oxford: Oxford University Press.

Kuhn, T. S. 1962. The Structure of Scientific Revolutions. Chicago, IL: University of Chicago Press.

LaBarre, W. 1977. The Ghost Dance: The Origins of Religion. New York: Delta Books.

Laughlin, R. B. 2005. A Different Universe: Reinventing Physics from the Bottom Down. New York: Basic Books.

Laughlin, C. D., and d'Aquili, E. G. 1974. Biogenetic Structuralism. New York: Columbia University Press.

Laughlin, C. D., McManus, J., and d'Aquili, E. G. 1990. Brain, Symbol \& Experience: Toward a Neurophenomenology of Human Consciousness. Boston, MA: Shambhala Publications.

Lewis, M. E. 1971. Sanctioned Violence in Early China. Albany, NY: State University of New York Press.

Lindberg, D. C. 2007. The Beginnings of Western Science: The European Scientific Tradition in Philosophical, Religious, and Institutional Context, Prehistory to A.D. 1450. Chicago, IL: The University of Chicago Press.

Marx, K. 1844. A Contribution to the Critique of Hegel's Philosophy of Right. URL: https://www.marxists.org/archive/marx/works/1843/cri tiquehpr/intro.htm. Accessed 07/03/2018.

Modelski, G. 2003. World Cities, -3000 to 2000. Washington, DC: Faros.

Newberg, A., and Waldman, M. R. 2010. How God Changes Your Brain: Breakthrough Findings from a Leading Neuroscientist. New York: Ballentine Books.

Nongbri, B. 2013. Before Religion: A History of a Modern Concept. New Haven, CT: Yale University Press.

Norenzayan, A. 2015. Big Gods: How Religion Transformed Cooperation and Conflict. Princeton, NJ: Princeton University Press.

Pagels, E. 1979. The Gnostic Gospels. New York: Random House.

Ramachandran, V. S. 2011. The Tell-Tale Brain: A Neuroscientist's Quest for What Makes Us Human. New York: W.W. Norton \& Co.

Rappaport, R. A. 1999. Ritual and Religion in the Making of Humanity. Cambridge: Cambridge University Press.

Rossano, M. J. 2010. Supernatural Selection: How Religion Evolved. Oxford: Oxford University Press.

Rue, L. 2005. Religion Is Not about God: How Spiritual Traditions Nurture Our Biological Nature and What to Expect When They Fail. New Brunswick, NJ: Rutgers University Press. 
Russell, B. 1957. Why I Am Not a Christian. New York: Touchstone Books.

Schwartz, B. I. 1985. The World of Thought in Ancient China. Cambridge, MA: The Belknap Press.

Seligman, A. B., Weller, R. P., Puett, M. J., and Simon, B. 2008. Ritual and Its Consequences: An Essay on the Limits of Sincerity. Oxford: Oxford University Press.

Slingerland, E. 2003. Effortless Action: Wu-Wei as Conceptual Metaphor and Spiritual Ideal in Early China. Oxford: Oxford University Press.

Smith, W. C. 1991 [1962]. The Meaning and End of Religion. Minneapolis, $\mathrm{MN}$ : Fortress Press.

Smolin, L. 2013. Time Reborn: From the Crisis in Physics to the Future of the Universe. Boston, MA: Houghton Mifflin Harcourt.

Stark, R. 2011. The Triumph of Christianity: How the Jesus Movement Became the World's Largest Religion. New York: Harper One.

Turner, J. H., Maryanski, A., Petersen, A. K., and Geertz, A. W. 2018. The Emergence and Evolution of Religion: By Means of Natural Selection. New York: Routledge.

van Schaik, C., and Michel, K. 2016. The Good Book of Human Nature: An Evolutionary Reading of the Bible. New York: Basic Books.

von Uexküll, J. 2010 [1934]. A Foray into the Worlds of Animals and Humans. Transl. by J. D. O'Neil. Minneapolis, MI: University of Minnesota Press.

Wallace, A. F. C. 1966. Religion: An Anthropological View. New York: Random House.

Wilson, D. S. 2002. Darwin's Cathedral: Evolution, Religion, and the Nature of Society. Chicago, IL: The University of Chicago Press.

Wilson, P. H. 2009. The Thirty Years War: Europe's Tragedy. Cambridge, MA: The Belknap Press.

Winzeler, R. L. 2012. Anthropology and Religion: What We Know Think, and Question. Lanham, MD: Altamira Press.

Yinger, J. M. 1970. The Scientific Study of Religion. New York: Macmillan Publishing Co. 